Editorial

\title{
Ecosystem Services: The Key to Human Well-Being
}

\author{
Alessandro Paletto ${ }^{1, *(\mathbb{D})}$ and Sara Favargiotti ${ }^{2}[\mathbb{D}$ \\ 1 Forest and Wood Research Center, Consiglio per la Ricerca in Agricoltura e l'Analisi dell'Economia \\ Agraria (CREA), p.za Nicolini 1, 38123 Trento, Italy \\ 2 Department of Civil, Environmental and Mechanical Engineering, University of Trento, 38122 Trento, Italy; \\ sara.favargiotti@unitn.it \\ * Correspondence: alessandro.paletto@crea.gov.it
}

Citation: Paletto, A.; Favargiotti, S. Ecosystem Services: The Key to Human Well-Being. Forests 2021, 12, 480. https://doi.org/10.3390/ f12040480

Received: 23 March 2021

Accepted: 12 April 2021

Published: 14 April 2021

Publisher's Note: MDPI stays neutral with regard to jurisdictional claims in published maps and institutional affiliations.
Since the publication of the Millennium Ecosystem Assessment (MEA), the global interest for "ecosystem services" has rapidly grown in scientific studies and policy makers' agenda. At the international level, many initiatives-i.e., the Economics of Ecosystem Services and Biodiversity (TEEB), the Common International Classification of Ecosystem Services (CICES), and the Intergovernmental Platform for Biodiversity and Ecosystem Services (IPBES) - have analyzed and incorporated the ecosystem services framework in the environmental and forestry policy targets. Therefore, in the last two decades the concept of ecosystem services has become the leitmotiv of natural resource management. The scientific community is analyzing the ecosystem services from different theoretical and practical perspectives, with the aim to integrate biophysical, economic and social aspects in a global framework. Starting from these considerations, the aim of the Special Issue "Assessing, Valuing and Mapping Ecosystem Services" (https: //www.mdpi.com/journal/forests/special_issues/Assessing_Ecosystem—accessed on 14 April 2021) is to promote the debate and the sharing of knowledge and experiences about assessing, valuing and mapping ecosystem services provided by natural, seminatural, and urban forests. The 13 papers published deal with the biophysical assessment and socio-economic evaluation of four categories of ecosystem services as classified by the MEA, as follows: provisioning, regulating, supporting, and cultural services. Four papers focus on the following ecosystem services provided by green infrastructures and urban forests: Krajter Ostoić et al. [1] provided basis for the quantification of cultural ecosystem services from tree-based urban green space in the city of Zagreb (Croatia), while Battisti et al. [2] assessed and mapped green area ecosystem services-provisioning and regulating services - of the city of Turin (Italy). Instead, Matasov et al. [3] investigated the feasibility of a network of wireless, low cost, and multiparameter monitoring devices, Tree Talkers (TT+), to monitor single-tree eco-physiological parameters in a green area located in the city of Moscow (Russia). Sacchelli et al. [4] assessed psychological and physiological responses of people when exposed to different forest stands (Turkey oak, European beech, black pine and Douglas-fir stands) compared to urban areas. Another two papers considered the provisioning services (non-wood forest products), as follows: Izumi [5] focused on what kinds of forest products-e.g., shiitake mushrooms, charcoal, and fuelwood-were historically used and shipped in 642 villages in the late 19th century in Iwate Prefecture (Japan), while Olah et al. [6] estimated the potential of forest stands for edible mushroom growing in a case study in central Slovakia (Banskobystrický self-governing region). Another five papers analyzed the regulating services (i.e., water cycle, natural hazard protection, and climate change mitigation) from an interdisciplinary perspective, as follows: Báliková et al. [7] analyzed and compared stakeholders' opinions toward the water-related ecosystem services provided by forests (142 stakeholders from 23 countries), while Vuletić et al. [8] investigated financing schemes of the forests and water sectors in four Southeast European countries (Bosnia and Herzegovina, Croatia, Serbia, and Slovenia), with the aim to understand the relationship between the existing payments for ecosystem 
services (PES) schemes and the theoretical PES definition. Accastello et al. [9] proposed and tested a harmonized model-ASFORESEE (Alpine Space FORest Ecosystem Services Economic Evaluation) - for economic evaluation of forest protection against rockfalls in a case study in the Italian Alps. Ovando and Speich [10] developed an uneven-aged forest economic decision-making model that determines the harvesting schedules and forest structure capable to maximize landowner revenues in a spatially explicit way, when both timber and water have an economic value. Always in the regulating services category, Flores-Hernández et al. [11] estimated Agave lechuguilla Torr. aboveground biomass for determining the carbon stores (regulating services) in natural ecosystems in three states in Mexico (Coahuila, San Luís Potosí, and Zacatecas). The last two papers focused on stakeholders' opinions towards multiple ecosystem services, as follows: Case et al. [12] investigated the opinions of 24 Native Americans (tribal members and representatives of tribal organizations) toward 78 resources and species divided into six groups of benefits, whereas Schneider et al. [13] involved 53 stakeholders (forester managers and nature conservation authorities) in a consultation process with the aim to understand the ecosystem services provided by protected areas (Natura 2000 sites) in the Czech Republic.

Funding: This research received no external funding.

Conflicts of Interest: The authors declare no conflict of interest.

\section{References}

1. Krajter Ostoić, S.; Marin, A.M.; Kičić, M.; Vuletić, D. Qualitative Exploration of Perception and Use of Cultural Ecosystem Services from Tree-Based Urban Green Space in the City of Zagreb (Croatia). Forests 2020, 11, 876. [CrossRef]

2. Battisti, L.; Pomatto, E.; Larcher, F. Assessment and Mapping Green Areas Ecosystem Services and Socio-Demographic Characteristics in Turin Neighborhoods (Italy). Forests 2020, 11, 25. [CrossRef]

3. Matasov, V.; Marchesini, L.B.; Yaroslavtsev, A.; Sala, G.; Fareeva, O.; Seregin, I.; Castaldi, S.; Vasenev, V.; Valentini, R. IoT Monitoring of Urban Tree Ecosystem Services: Possibilities and Challenges. Forests 2020, 11, 775. [CrossRef]

4. Sacchelli, S.; Grilli, G.; Capecchi, I.; Bambi, L.; Barbierato, E.; Borghini, T. Neuroscience Application for the Analysis of Cultural Ecosystem Services Related to Stress Relief in Forest. Forests 2020, 11, 190. [CrossRef]

5. Izumi, K. Spatial Distribution of Local Forest Products at the End of the 19th Century: A Case Study of Former Villages in Iwate Prefecture. Forests 2020, 11, 1044. [CrossRef]

6. Olah, B.; Kunca, V.; Gallay, I. Assessing the Potential of Forest Stands for Ectomycorrhizal Mushrooms as a Subsistence Ecosystem Service for Socially Disadvantaged People: A Case Study from Central Slovakia. Forests 2020, 11, 282. [CrossRef]

7. Báliková, K.; Červená, T.; De Meo, I.; De Vreese, R.; Deniz, T.; El Mokaddem, A.; Kayacan, B.; Larabi, F.; Lỉbiete, Z.; Lyubenova, M.; et al. How Do Stakeholders Working on the Forest-Water Nexus Perceive Payments for Ecosystem Services? Forests 2019, 11, 12. [CrossRef]

8. Vuletić, D.; Ostoić, S.K.; Keča, L.; Avdibegović, M.; Potočki, K.; Posavec, S.; Marković, A.; Pezdevšek Malovrh, Š. Water-Related Payment Schemes for Forest Ecosystem Services in Selected Southeast European (SEE) Countries. Forests 2020, 11, 654. [CrossRef]

9. Accastello, C.; Bianchi, E.; Blanc, S.; Brun, F. ASFORESEE: A Harmonized Model for Economic Evaluation of Forest Protection against Rockfall. Forests 2019, 10, 578. [CrossRef]

10. Ovando, P.; Speich, M. Optimal Harvesting Decision Paths When Timber and Water Have an Economic Value in Uneven Forests. Forests 2020, 11, 903. [CrossRef]

11. Flores-Hernández, C.D.J.; Méndez-González, J.; Sánchez-Pérez, F.D.J.; Méndez-Encina, F.M.; López-Díaz, Ó.M.; López-Serrano, P.M. Allometric Equations for Predicting Agave lechuguilla Torr. Aboveground Biomass in Mexico. Forests 2020, 11, 784. [CrossRef]

12. Case, M.J.; Kim, J.B.; Kerns, B.K. Using a Vegetation Model and Stakeholder Input to Assess the Climate Change Vulnerabil-ity of Tribally Important Ecosystem Services. Forests 2020, 11, 618. [CrossRef]

13. Schneider, J.; Ruda, A.; Kalasová, Ž.; Paletto, A. The Forest Stakeholders' Perception towards the NATURA 2000 Network in the Czech Republic. Forests 2020, 11, 491. [CrossRef] 